\title{
Clinical and radiological responses to oral methotrexate alone or in combination with other agents in Erdheim-Chester disease
}

\author{
Gaurav Goyal', Mithun V. Shah', Timothy G. Call', C. Christopher Hook', William J. Hogan (1) and Ronald S. Go (1)
}

Erdheim-Chester disease (ECD) is a rare histiocytic disorder that is now included under hematopoietic neoplasm according to 2016 World Health Organization classification $^{1}$. Recently, identification of targetable MAP kinase pathway mutations like BRAF-V600E in ECD has changed the initial treatment approach in $50-70 \%$ of patients ${ }^{2,3}$. MEK inhibitors seem promising in patients with other activating MEK-ERK pathway mutations, but with limited experience $^{4,5}$. However, there is a paucity of data on therapeutic options in patients who do not harbor these mutations, who relapse after targeted therapy, and who do not have adequate tissue available for genomic testing. Historically, interferon alfa and cladribine have been utilized with variable efficacy ${ }^{6,} 7$. There have been some reports of successful treatment of Langerhans Cell Histiocytosis with oral methotrexate ${ }^{8,} 9$. In this study, we report our institution's experience with oral methotrexate in treatment of ECD.

After obtaining consent waiver and approval from the institutional review board, we retrospectively reviewed the medical records of ECD patients evaluated at Mayo Clinic from 1 January 1998 to 6 April 2016 who received methotrexate. The diagnosis of ECD was made by using clinical criteria in conjunction with histopathologic findings ${ }^{10}$. All the biopsy specimens were independently reviewed at our institution.

Since post-therapy response assessment was not uniformly performed, we used previously published clinical and radiological response criteria ${ }^{7}$. The clinical responses were divided into: (i) complete freedom from symptoms attributed to ECD (complete response or CR); (ii) significant improvement, but not complete resolution, of the symptoms attributed to ECD (partial response or PR); (iii)

Correspondence: Ronald S Go (Go.Ronald@mayo.edu)
${ }^{1}$ Division of Hematology, Mayo Clinic, Rochester, MN, USA no significant change in the symptoms attributed to ECD (stable disease or SD); (iv) significant worsening of symptoms attributed to ECD (progressive disease or PD). The minimum duration for symptom improvement to be considered a response was arbitrarily set at 3 months.

Radiological response to therapy was assessed using the imaging studies available. In our series, a large proportion of patients did not undergo positron emission tomography-computed tomography (PET-CT) scans and responses were assessed based on alternative imaging studies available: X-rays, magnetic resonance imaging, computed tomography scans, and radionuclide bone scans. The radiologic responses were categorized as follows based on the change in the size or appearance of lesion(s) suspected/proven to be ECD: (i) CR: complete resolution; (ii) PR: significant improvement (decrease in activity or size by any degree), but not complete resolution; (iii) SD: no significant change for $\geq 3$ months); and (iv) PD: significant progression.

A total of 63 patients with ECD were identified. The median age at diagnosis was 54 years (range, $34-80$ years). Methotrexate was administered to 13 (21\%) of the patients. The median age at diagnosis of the latter cohort was 51 years (age range, 34-66 years), and 7 (54\%) were male. Organs involved included: bone (85\%), central nervous system (54\%), kidney/retroperitoneum (54\%), cardiovascular system (38\%), lung (23\%), and skin (23\%; Table 1). Methotrexate was administered as first-line therapy for six patients and second/subsequent line of therapy for the remaining seven patients (range, 1-6). The median duration of therapy was 4 months (range, 1-163). The most commonly used dose for methotrexate was 15 $\mathrm{mg} /$ week orally (range, $7.5-25 \mathrm{mg}$ ). It was administered as a single agent in three patients, in combination with prednisone in six patients, and in combination with other biologics (etanercept or infliximab) in four patients. 
Table 1 Individual patient characteristics for 13 Erdheim-Chester disease patients treated with methotrexate (MTX)

\begin{tabular}{|c|c|c|c|c|c|c|c|c|c|c|c|}
\hline & $\begin{array}{l}\text { Age at } \\
\text { diagnosis/ } \\
\text { sex }\end{array}$ & Sites/organs involved & $\begin{array}{l}\text { Prior } \\
\text { therapies }\end{array}$ & Treatment & $\begin{array}{l}\text { Weekly } \\
\text { oral } \\
\text { dose of } \\
\text { MTX }\end{array}$ & $\begin{array}{l}\text { Duration } \\
\text { of MTX } \\
\text { (months) }\end{array}$ & $\begin{array}{l}\text { Clinical } \\
\text { response }\end{array}$ & $\begin{array}{l}\text { Radiologic } \\
\text { response }\end{array}$ & $\begin{array}{l}\text { BRAF } \\
\text { V600E } \\
\text { mutation }\end{array}$ & Comments & $\begin{array}{l}\text { Dead/ } \\
\text { alive } \\
\text { (age) }\end{array}$ \\
\hline 1 & $51 / \mathrm{M}$ & Pharynx, bones/joints & None & $\begin{array}{l}\text { MTX + } \\
\text { prednisone + } \\
\text { etanercept/ } \\
\text { infliximab }\end{array}$ & $17.5 \mathrm{mg}$ & 15 & PD & PD & ND & $\begin{array}{l}\text { Increase in size of } \\
\text { the pharyngeal } \\
\text { lesion, arthralgia }\end{array}$ & $\begin{array}{l}\text { Alive } \\
\text { (58) }\end{array}$ \\
\hline 2 & $64 / F$ & $\begin{array}{l}\text { Bone, bone marrow, } \\
\text { lung, liver, spleen, } \\
\text { lymph nodes, CVS }\end{array}$ & None & $\begin{array}{l}\text { MTX+ } \\
\text { Infliximab }\end{array}$ & $20 \mathrm{mg}$ & 4 & PD & PD & $\begin{array}{l}\text { Present } \\
\text { (PCR) }\end{array}$ & $\begin{array}{l}\text { Worsening } \\
\text { symptoms, } \\
\text { splenomegaly and } \\
\text { lymphadenopathy }\end{array}$ & $\begin{array}{l}\text { Alive } \\
\text { (67) }\end{array}$ \\
\hline 3 & 39/M & Orbit & None & $\begin{array}{l}\text { MTX+ } \\
\text { prednisone }\end{array}$ & $25 \mathrm{mg}$ & 3 & PD & PD & ND & $\begin{array}{l}\text { Worsening eye } \\
\text { symptoms and PET- } \\
C T\end{array}$ & $\begin{array}{l}\text { Dead } \\
(41)\end{array}$ \\
\hline 4 & $47 / F$ & $\begin{array}{l}\text { Bone, CNS, lung, } \\
\text { kidney, } \\
\text { retroperitoneum }\end{array}$ & Prednisone & $\begin{array}{l}\text { MTX }+ \\
\text { prednisone }\end{array}$ & $20 \mathrm{mg}$ & 4 & PD & SD & $\begin{array}{l}\text { Present } \\
(\mathrm{IHC})\end{array}$ & $\begin{array}{l}\text { Worsening pleuritis/ } \\
\text { pericarditis and } \\
\text { stable MRI head }\end{array}$ & $\begin{array}{l}\text { Alive } \\
\text { (52) }\end{array}$ \\
\hline 5 & $59 / \mathrm{M}$ & Bone, CNS & None & $\begin{array}{l}\text { MTX }+ \\
\text { prednisone }\end{array}$ & $15 \mathrm{mg}$ & 4 & PD & UNK & ND & Worsening diplopia & UNK \\
\hline 6 & 49/M & $\begin{array}{l}\text { Bone, CNS, lung, CVS, } \\
\text { kidney, } \\
\text { retroperitoneum }\end{array}$ & $\begin{array}{l}\text { Prednisone } \\
\text { Cyt }\end{array}$ & $\begin{array}{l}\text { MTX+ } \\
\text { prednisone }\end{array}$ & $12.5 \mathrm{mg}$ & 12 & $P R$ & PD & $\begin{array}{l}\text { Present } \\
\text { (PCR) }\end{array}$ & $\begin{array}{l}\text { Improved } \\
\text { abdominal pain for } \\
6 \text { months, MRI worse } \\
\text { after that }\end{array}$ & UNK \\
\hline 7 & $59 / F$ & $\begin{array}{l}\text { Bone, CNS, kidney, } \\
\text { retroperitoneum }\end{array}$ & Prednisone & $\begin{array}{l}\text { MTX+ } \\
\text { prednisone }\end{array}$ & $20 \mathrm{mg}$ & 7 & PD & PD & $\begin{array}{l}\text { Present } \\
\text { (PCR) }\end{array}$ & $\begin{array}{l}\text { New femoral lesions } \\
\text { and bone pain }\end{array}$ & $\begin{array}{l}\text { Alive } \\
(62)\end{array}$ \\
\hline 8 & $66 / F$ & $\begin{array}{l}\text { Orbit, tibia, periaortic } \\
\text { area, liver, spleen }\end{array}$ & None & MTX & UNK & 6 & PD & UNK & ND & Worsening arthralgia & $\begin{array}{l}\text { Dead } \\
(67)\end{array}$ \\
\hline 9 & $57 / \mathrm{M}$ & $\begin{array}{l}\text { Bone, bone marrow, } \\
\text { CVS, kidney, } \\
\text { retroperitoneum }\end{array}$ & Prednisone & $\begin{array}{l}\text { MTX + } \\
\text { infliximab + } \\
\text { prednisone }\end{array}$ & $15 \mathrm{mg}$ & 3 & PD & SD & $\begin{array}{l}\text { Present } \\
\text { (PCR) }\end{array}$ & $\begin{array}{l}\text { Worsening } \\
\text { symptoms but MRI } \\
\text { heart stable }\end{array}$ & $\begin{array}{l}\text { Alive } \\
\text { (61) }\end{array}$ \\
\hline 10 & $49 / F$ & CNS, retroperitoneum & Prednisone & $\begin{array}{l}\text { MTX+ } \\
\text { prednisone }\end{array}$ & $15 \mathrm{mg}$ & $24+$ & $P R$ & SD & $\begin{array}{l}\text { Absent } \\
\text { (PCR) }\end{array}$ & Vision improved & $\begin{array}{l}\text { Alive } \\
\text { (52) }\end{array}$ \\
\hline 11 & $34 / F$ & Bone, CNS, skin & None & $\begin{array}{l}\text { MTX }+ \\
\text { infliximab }\end{array}$ & UNK & 25 & SD & SD & $\begin{array}{l}\text { Present } \\
(\mathrm{HC})\end{array}$ & $\begin{array}{l}\text { Worsening dizziness } \\
\text { and imaging after } \\
25 \text { months }\end{array}$ & $\begin{array}{l}\text { Alive } \\
\text { (37) }\end{array}$ \\
\hline 12 & $54 / \mathrm{M}$ & $\begin{array}{l}\text { Bone, CNS, skin, kidney, } \\
\text { retroperitoneum }\end{array}$ & Prednisone & MTX & $15 \mathrm{mg}$ & 1 & PD & PD & $\begin{array}{l}\text { Present } \\
\text { (urine } \\
\text { P(R) }\end{array}$ & $\begin{array}{l}\text { New skin lesions, } \\
\text { worsening vasculitis }\end{array}$ & $\begin{array}{l}\text { Alive } \\
\text { (57) }\end{array}$ \\
\hline 13 & $44 / \mathrm{M}$ & $\begin{array}{l}\text { Bone, bone marrow, } \\
\text { CNS, kidney, } \\
\text { retroperitoneum, skin, } \\
\text { vas deferens }\end{array}$ & $\begin{array}{l}\text { Tamoxifen } \\
\text { Prednisone } \\
\text { Azathioprine } \\
\text { Cyt }\end{array}$ & MTX & $7.5 \mathrm{mg}$ & $163+$ & $P R$ & SD & ND & $\begin{array}{l}\text { Improved vision and } \\
\text { paresthesia, stable } \\
\text { epidural mass on } \\
\text { MRI }\end{array}$ & $\begin{array}{l}\text { Alive } \\
\text { (59) }\end{array}$ \\
\hline
\end{tabular}

aUrine-based circulating tumor DNA test.

CNS central nervous system, $C R$ complete remission, $C T$ computed tomography, $C V S$ cardiovascular system, Cyt cyclophosphamide, ECD Erdheim-Chester disease, $F$ female, IHC immunohistochemistry, M male, MTX methotrexate, MRI magnetic resonance imaging, ND not done, NE non-evaluable (due to lack of follow-up visit/ imaging), NGS next-generation sequencing, $P C R$ polymerase chain reaction, $P D$ progressive disease, $P E T$ - $C T$ positron emission tomography-computed tomography, $P R$ partial remission, SD stable disease, UNK unknown

The overall clinical response rate to methotrexate therapy was $23 \%(0 / 13 \mathrm{CR}$ and $3 / 13 \mathrm{PR})$, with SD in $7 \%$ $(1 / 13)$ and $\mathrm{PD}$ in $70 \%(9 / 13)$ patients. Among the three patients who responded to methotrexate therapy, the duration of response was 12, 24, and 163 months, respectively. The latter two patients remained on continuous methotrexate therapy, with ongoing response. Both of them had ECD involving the eyes (subconjunctival and choroidal) and noted improvement in vision with methotrexate. Among the three patients who received methotrexate alone, two had PD and one had PR ongoing after treatment for 163 months, with time to response of 4 months. The overall radiologic response rate was $0 \%$, with SD in $38 \%(5 / 13), \mathrm{PD}$ in $46 \%(6 / 13)$, and unknown in $16 \%(2 / 13)$ patients (Table 1$)$. Treatment- related notable adverse effects were seen in one patient who developed CTCAE grade 3 infection (cellulitis requiring hospitalization). Another patient developed grade 3 hyperglycemia that was deemed secondary to the concomitant corticosteroid use. Grade $1 \quad(<3$ times upper limit) liver function test abnormalities were noted in three (23\%) patients. BRAF V600E mutation testing was performed in eight patients, seven of which were positive. Of the seven patients with $B R A F$ V600E mutation, six ultimately went on to receive BRAF-inhibitor treatment. At last follow-up, two patients had died, and the causes of death were unknown.

In our series, methotrexate had a low clinical activity. However, the clinical benefit could be sustained, as demonstrated by the two patients who continue to be in remission after 2 and 13 years, respectively. Methotrexate 
was well tolerated overall, and all treatment discontinuations were due to progressive disease. There were no improvements in radiological manifestations of the disease, even in patients who experienced a clinical response. It is to be noted that both of the patients with ongoing responses did not undergo a PET-CT, which usually is the modality of choice to monitor radiological response ${ }^{10}$. This highlights the underlying chronic fibro-inflammatory nature of the disease that often fails to regress if measured by conventional imaging studies. The two patients who had a treatment response to methotrexate had ocular involvement. The exact reason for activity of methotrexate in ocular ECD is unclear, although there is a previous large study demonstrating its efficacy in other ocular inflammatory diseases as well ${ }^{11}$. In contrast to ocular responses, two other patients who had periorbital disease failed to respond to methotrexate therapy. These findings may indicate its role primarily in ocular ECD.

There are limited existing data on the treatment of ECD with oral methotrexate. One of the first case reports of the use of this agent in ECD involved the use of high-dose intravenous methotrexate for central nervous system disease $^{12}$. This case demonstrated rapid improvement of neurological signs and symptoms in a patient with relapsed ECD who was otherwise declining neurologically. Another case series included one patient with ECD who presented with visual abnormalities and exophthalmos due to periorbital disease that worsened despite therapy with methotrexate ${ }^{6}$. A recently published ECD series included two patients who achieved disease stability with methotrexate, and no objective responses were reported ${ }^{13}$.

The main limitation of our study can be ascribed to it being a single-institution retrospective study that might limit the generalizability of our results. Our study included patients from the past 18 years, and there is heterogeneity in terms of advances in imaging, histopathological techniques of diagnosis, as well as supportive care that cannot be accounted for. In addition, post-therapy response assessment was not uniformly performed in a prospective manner. However, to minimize the chances of errors or bias, the charts were independently reviewed by three investigators.

To our knowledge, this study is the largest series reviewing the efficacy of oral methotrexate in ECD. This highlights the challenges in conducting large ECD studies owing to the rarity of this condition. If no MAP kinase alterations are identified, the role of methotrexate is perhaps limited to second-line or third-line therapies in the presence of established agents like interferon alpha and perhaps cladribine. However, it may be considered a treatment option in primarily ocular ECD. Needless to say, in the right context, it may serve as the treatment of choice depending on patient preference, toxicity profile, and ease of administration. Our study also calls for more studies on other therapeutic targets and novel agents in ECD patients who do not possess MAP-kinase alterations.

\section{Acknowledgements}

This study was presented as a poster at Erdheim-Chester disease Global Alliance symposium which was held in New York, NY, on 26 October 2017.

\section{Authors' contributions}

G.G. and R.S.G. had full access to all the data in the study and take responsibility for the integrity of the data and the accuracy of the data analysis. Concept and design: G.G., R.S.G.; acquisition, analysis, or interpretation of data: G.G., R.S.G., M. V. S.; drafting of the manuscript: G.G., R.G.S.; critical revision of the manuscript for important intellectual content: G.G., R.S.G., T.G.C., C.H., W.J.H.; statistical analysis: G.G.; supervision: R.S.G.

\section{Funding}

This research did not require any funding or financial support.

\section{Competing interests}

The authors declare that they have no competing interests.

\section{Publisher's note}

Springer Nature remains neutral with regard to jurisdictional claims in published maps and institutional affiliations.

Received: 2 August 2017 Revised: 26 September 2017 Accepted: 10 October 2017

Published online: 15 December 2017

\section{References}

1. Swerdlow, S. H. et al. The2016 revision of the World Health Organization classification of lymphoid neoplasms. Blood 127, 2375-2390 (2016).

2. Haroche, J. et al. High prevalence of BRAF V600E mutations in ErdheimChester disease but not in other non-Langerhans cell histiocytoses. Blood 120, 2700-2703 (2012).

3. Diamond, E. L., et al. Vemurafenib in Patients with Erdheim-Chester Disease (ECD) and Langerhans Cell Histiocytosis (LCH) Harboring BRAF(V600) Mutations: a cohort of the Histology-Independent VE-Basket Study. Blood 128, 480 (2016)

4. Diamond, E. L. et al. Diverse and targetable kinase alterations drive histiocytic neoplasms. Cancer Discov. 6, 154-165 (2016).

5. Cohen Aubart, F. et al. Targeted therapies in 54 patients with Erdheim-Chester disease, including follow-up after interruption (the LOVE study). Blood 130, 1377-1380 (2017).

6. Braiteh, F., Boxrud, C., Esmaeli, B. \& Kurzrock, R. Successful treatment of Erdheim-Chester disease, a non-Langerhans-cell histiocytosis, with interferonalpha. Blood 106, 2992-2994 (2005).

7. Goyal, G. et al. Clinical and radiologic responses to cladribine for the treatment of Erdheim-Chester disease. JAMA Oncol. 3, 1253-1256 (2017).

8. Womer, R. B., Anunciato, K. R. \& Chehrenama, M. Oral methotrexate and alternate-day prednisone for low-risk Langerhans cell histiocytosis. Med. Pediatr. Oncol. 25, 70-73 (1995).

9. Steen, A. E., Steen, K. H., Bauer, R. \& Bieber, T. Successful treatment of cutaneous Langerhans cell histiocytosis with low-dose methotrexate. Br. J. Dermatol. 145, 137-140 (2001).

10. Diamond, E. L. et al. Consensus guidelines for the diagnosis and clinical management of Erdheim-Chester disease. Blood 124, 483-492 (2014).

11. Gangaputra, S. et al. Methotrexate for ocular inflammatory diseases. Ophthalmology 116, 2188-2198 (2009). e2181.

12. Ho, P. \& Smith, C. High-dose methotrexate for the treatment of relapsed central nervous system erdheim-chester disease. Case Rep. Hematol. 2014, 269359 (2014)

13. Estrada-Veras, J. I. et al. The clinical spectrum of Erdheim-Chester disease: an observational cohort study. Blood Adv. 1, 357-366 (2017). 